\title{
THE MARINE BIOLOGICAL ASSOCIATION OF THE UNITED KINGDOM
}

ThE Association was founded in $\mathbf{1 8 8 4}$ to promote accurate researches leading to the advancement of zoological and botanical science and to an increase in our knowledge of the food, life, conditions and habits of British fishes. The work of the Association is controlled by a Council elected annually by its subscribing members.

Professor T. H. Huxley took the chair at the initial meeting held in the rooms of the Royal Society and was elected the first President. Among those present were Sir John Lubbock (afterwards Lord Avebury), Sir Joseph Hooker, Professor H. N. Moseley, Mr G. J. Romanes, and Sir E. Ray Lankester who, after Professor Huxley, was for many years president of the Association. It was decided to build a laboratory at Plymouth, where a rich and varied fauna is found.

The Plymouth Laboratory was opened in June 1888, and, since that date, considerable additions have been made to the buildings, including a library, lecture-hall, and extensive laboratory accommodation with up-to-date equipment. Additional sea-water reservoirs have also been built, and an aquarium, modernized in 1959, opened to the public.

Since its foundation the Association has been supported by subscriptions and donations from private members, universities, learned societies, the Fishmongers' Company and other public bodies. For some time past, however, the main financial support for the work of the Plymouth Laboratory has come from Government funds, and since 1965 the Laboratory has been grant-aided through the Natural Environment Research Council.

The Marine Biological Association, under the direction of its Council, undertakes research in all branches of marine science and the main results are published in this journal. Accounts of the laboratory and aquarium are to be found in Vol. 27 (p. 761), Vol. 39 (p. 391) and Vol. 43 (p. 281), and summaries of the activities and research of the Association are given annually in the Report of the Council in the November issue of the Journal.

The laboratory is open throughout the year and its work is carried out by a fully qualified research staff under the supervision of the Director. The names of the members of the staff will be found on the inner page of the front cover. Accommodation is available for British and foreign scientific workers who wish to carry out independent research in all branches of marine science. Arrangements are made for courses for advanced students, and marine animals and plants are supplied to educational institutions.

Work at sea is undertaken by three research vessels and by a motor boat, and these also collect the specimens required in the laboratory.

\section{TERMS OF MEMBERSHIP}

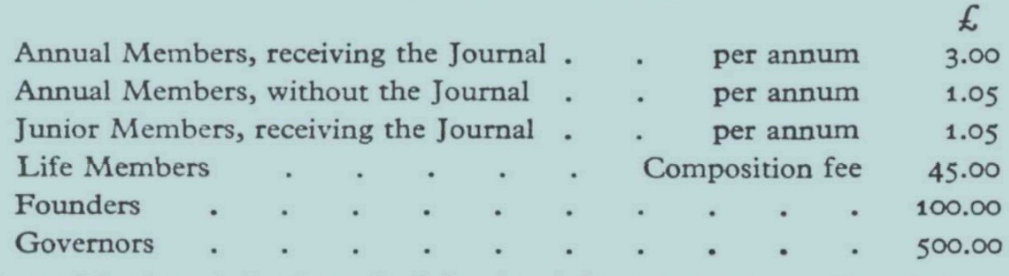

Members of the Association have the following rights and privileges: they elect annually the Officers and Council; they are entitled to receive the Journal of the Association at a reduced rate; they are admitted to view the laboratory at Plymouth; they have the first claim to rent a place in the laboratory for research, with use of tanks, boats, etc; they have the privilege of occupying a table for one week in each year free of charge; and they have access to the books in the library at Plymouth during working hours.

The Commissioners of Inland Revenue have approved the Association for the purposes of Section 16, Finance Act, 1958, and that the whole of the annual subscription paid by a member who qualifies for relief under the section will be allowable as a deduction from his emoluments assessable to income tax under Schedule E.

All correspondence should be addressed to the Director, The Laboratory, Citadel Hill, Plymouth, PL $12 \mathrm{~PB}$. 


\title{
CONTENTS
}

RoE, H. S. J. The vertical distributions and diurnal migrations of calanoid copepods collected on the SOND Cruise, 1965. I. The total population and general discussion . .

RoE, H. S. J. The vertical distributions and diurnal migrations of calanoid copepods collected on the SOND Cruise, 1965 . II. Systematic account: families Calanidae up to and including the Aetideidae

WALNE, P. R. The influence of current speed, body size and water temperature on the filtration rate of five species of bivalves . . . . . . . . . .

HARRIS, ROGER P. Horizontal and vertical distribution of the interstitial harpacticoid copepods of a sandy beach . . . . . . . . . . . .

HARRIS, ROGER P. Seasonal changes in the meiofauna population of an intertidal sand beach

LARKUM, A. W. D. Frond structure and growth in Laminaria hyperborea . . . . 405

JONES, M. B. Osmoregulation in the faera albifrons group of species [Isopoda, Asellota] . 419

WALKER, G. The biochemical composition of the cement of two barnacle species, Balanus hameri and Balamus crenatus.

CRISP, MARY. Photoreceptive function of an epithelial receptor in Nassarius reticulatus [Gastropoda, Prosobranchia] . . . . . . . . . . . .

StebBing, A. R. D. and Dilly, P. N. Some observations on living Rhabdopleura compacta [Hemichordata]

GRUFFYDD, LL. D. Mortality of scallops on a Manx scallop bed due to fishing

White, I. C. On the ecology of an adult digenetic trematode Proctoeces subtenuis from a lamellibranch host Scrobicularia plana . . . . . . . . . .

GreEN, J. C. and LEADBEATER, B. S. C. Chrysochromulina parkeae sp.nov. [Haptophyceae] a new species recorded from S.W. England and Norway

ARNOLD, D. C. Salinity tolerances of some common prosobranchs _ . . . . . . 475

CoRnelius, P. F. S. Second occurrence of Stygiomedusa fabulosa [Scyphozoa] . . . . . 487

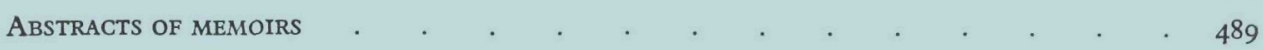

The subscription price of the Journal to non-members of the Association is $£ 22.00$ net a volume of four parts, post free, or $\$ 70.00$ in U.S.A., payable in advance. Subscriptions may be sent to any bookseller or to the Cambridge University Press, and in U.S.A. to the Cambridge University Press American Branch.

\author{
CAMBRIDGE UNIVERSITY PRESS \\ BENTLEY HOUSE, 200 EUSTON ROAD, LONDON NW1 2 DB
}

AMERICAN BRANCH: 32 EAST 57TH STREET, NEW YORK, N.Y.10022

Printed in Great Britain at the University Printing House, Cambridge 